\title{
Meningkatkan Pembendaharaan Kosakata Bahasa Inggris Menggunakan Strategi Crossword Puzzle
}

\section{N. P. Yuana ${ }^{1 *}$, N. W. Muliani ${ }^{2}$, N. K. Wedhanti ${ }^{3}$}

${ }^{123}$ Jurusan Pendidikan Bahasa Inggris Universitas Pendidikan Ganesha

\section{ART I CLE I N F O}

Article history:

Received January 21, 2021

Revised February 03, 2021

Accepted April 08, 2021

Available online May 25, 2021

\section{Kata Kunci:}

Kosakata, Crossword Puzzle,

Penelitian Tindakan Kelas

Keywords:

English Vocabulary, Crossword

Puzzle, Classroom Action

Research

\begin{abstract}
A B S T R A K
Penelitian ini berkaitan dengan pembendaharaan kosakata Bahasa Inggris siswa kelas VIII. Latar belakang penelitian ini adalah hasil observasi peneliti pada kelas VIII A1 yang menunjukkan adanya kelemahan pembendaharaan kosakata Bahasa Inggris yang menyulitkan siswa untuk memproduksi Bahasa Inggris secara baik dan lancar. Dari latar belakang tersebut peneliti melaksanakan penelitian terkait penggunaan strategi pembelajaran crossword puzzle. Tujuan dari penelitian ini adalah untuk mengetahui keberhasilan penggunaan strategi crossword puzzle untuk meningkatkan pembendaharaan kosakata Bahasa Inggris siswa. Bentuk penelitian yang digunakan dalam penelitin ini adalah penelitian tindakan kelas karena permasalahan yang diangkat langsung ditemukan dari dalam kelas. 32 siswa kelas VIII A1 SMP Negeri 6 Singaraja menjadi subyek penelitian ini dengan latar belakang hasil observasi selama masa pelaksanaan praktek pengalaman lapangan (PPL). Data dikumpulkan dari hasil pre-test, post-test, dan questionnaire terkait respon siswa terhadap strategi yang digunakan. Kemudian data dianalisis dengan cara membandingkat peningkatan hasil test dan didukung dengan questionnaire. Hasil penelitian ini menemukan pembuktian keberhasilan penggunaan strategi crossword puzzle untuk meningkatkan pembendaharaan kosakata Bahasa Inggris siswa.
\end{abstract}

\begin{abstract}
A B S TRACT
This study deals with the eighth grader students' English vocabulary knowledge. The background of the research was based on the finding during the observation process in class VIII A1 that showed the students' weakness in vocabulary knowledge that caused the students felt difficult to produce a correct and fluent English. Based on that background the researcher conducted a research on the use of crossword puzzle learning strategy. The objective of this study was to know the effectiveness of the use of crossword puzzle strategy to increase students' English vocabulary. Classroom action research was applied in this research since the problem that been discussed was directly came from the class. The subject of this study were 32 students of class VIII A1 at SMP Negeri 6 Singaraja as the result of classroom observation during the real experience program. The data were collected from the result of pre-test, post-test, and questionnaire about students' response through the use of the strategy applied. The data were analyzed by comparing the results of the tests and supported with questionnaire. This study find the prove about the effectiveness of the use of crossword puzzle strategy to increase students' English vocabulary knowledge.
\end{abstract}

\section{Pendahuluan}

Pendidikan dan pengajaran adalah suatu proses yang sadar tujuan. Tujuan dapat diartikan sebagai suatu usaha untuk memberikan rumusan hasil yang diharapkan siswa setelah melaksanakan pengalaman belajar (Sadirman, 2004). Tercapai tidaknya tujuan pengajaran salah satunya adalah terlihat dari prestasi belajar yang diraih siswa. Dengan prestasi yang tinggi, para siswa mempunyai indikasi berpengetahuan yang baik (Njoroge, M.C., Ndung'u, R.W., Gathigia, 2013). Pengertian pendidikan dalam lingkungan sekolah mempunyai arti yang lebih luas dari pada mengajar. Mengajar lebih difokuskan pada proses transformasi pengetahuan yang bersifat afektif. Pendidikan merupakan proses komunikasi dua arah yang tidak hanya merupakan proses transformasi pengetahuan tetapi juga 2 proses internalisasi nilai-nilai karakter .Pendidikan secara etimologi berasal dari kata "paedagogie" dari bahasa Yunani, terdiri dari kata "pais" artinya anak dan "again" artinya membimbing, jadi jika diartikan, paedagogie artinya bimbingan yang diberikan kepada anak.1 Dalam bahasa Romawi pendidikan berasal dari kata "educate" yang berarti mengeluarkan sesuatu yang berada dari dalam.2 Sedangkan dalam bahasa Inggris pendidikan diistilahkan dengan kata "to educate" yang berarti memperbaiki moral dan melatih intelektual (Sholichah, 2018).

Bahasa merupakan alat komunikasi yang memegang peranan penting dalam kehidupan. Dengan menggunakan bahasa, seseorang dapat berinteraksi dengan manusia lain, mengekspresikan diri, mengungkapkan perasaan, menyampaikan ide, informasi maupun gagasan serta menyebarluaskan ilmu 
pengetahuan. Bahkan, melalui ragam bahasa tulis maupun lisan, bahasa dapat berperan menjadi pengantar yang paling efektif dan efisien dalam dunia pendidikan. Kemampuan dan keterampilan berbahasa dapat dilatih dan kemampuan dan keterampilan berbahasa memiliki peran penting dalam dikembangkan secara berkesinambungan dengan pembinaan sedini mungkin. Karena mengembangkan aspek-aspek kognitif, afektif dan psikomotorik sebagai penunjang keberhasilan siswa di masa yang akan dating (Sudrajat and Herlina, 2015). Bahasa memegang peranan sangat penting bagi kehidupan manusia. Bahasa merupakan rangkaian bunyi yang beraturan yang digunakan untuk mengungkapkan pikiran dan perasaan seseorang terhadap orang yang lain. Sehingga melalui bahasa, seorang manusia dapat mengungkapkan pikiran dan gagasan yang dimilikinya ( Dwi W 2007: 67). Bahasa menurut Hurlock (2008 : 176) berpendapat bahwa bahasa mencakup setiap sarana komunikasi dengan menyimpulkan pikiran dan perasaan untuk menyampaikan makna kepada orang lain (Astuti and Habibah, 2015) Bahasa mempunyai peranan yang penting dalam pengembangan aspek intelektual, sosial dan emosional siswa. Fungsi bahasa tidak hanya sebagai subyek atau sebuah mata pelajaran tetapi juga sebagai alat siswa untuk mengekspresikan ide atau pemikiran dan perasaan mereka dalam kehidupan sehari-hari baik di lingkungan masyarakat atau di lingkungan sekolah. Maka, setelah mempelajari bahasa, siswa diharapkan memiliki beberapa kemampuan khususnya kemampuan berbicara yang akan mampu membuat mereka berkomunikasi dengan baik dan benar. Terlebih, bahasa adalah sebuah sistem yang diciptakan oleh manusia untuk berkomunikasi (Kurikulum 2004:35). Definisi ini menunjukan bahwa semua orang membutuhkan bahasa untuk berkomunikasi dalam rangka penyampaian ide, gagasan serta perasaan mereka kepada lawan bicara (Ramdhan, 2017) Di dalam mempelajari bahasa, baik bahasa Indonesia, maupun bahasa asing dikenal beberapa aspek yang mendukung keberhasilan pembelajaran bahasa tersebut, salah satunya adalah perbendaharaan kata (vocabulary). Selanjutnya, mempelajari bahasa asing tidaklah mudah, sangat berbeda jika kita mempelajari bahasa ibu dan bahasa Indonesia (Zalmansyah, 2013).

Di era globalisasi menguasai bahasa Inggris merupakan sebuah keharusan. Kemampuan berbahasa Inggris menjadi salah satu nilai tambah. Bahasa Inggris diajarkan mulai dari level Sekolah Dasar, Sekolah Menengah Pertama, Sekolah Menengah Atas hingga level Perguruan Tinggi. Demikian Juga mahasiswa Sekolah Tinggi Kesehatan yang notabene merupakan mahasiswa non-Bahasa Inggris. Paramedis seperti dokter, perawat, bidan dan tenaga kesehatan harus menguasai bahasa inggris sebagai bahasa International Karena banyaknya peralatan medis dalam bahasa Inggris pun cara pengoperasianya menggunakan bahasa Inggris. Itu merupakan salah satu bukti pentingnya penguasaan Bahasa Inggris. Mata kuliah bahasa Inggris menjadi salah satu mata kuliah wajib yang harus dipelajari. Sinaga (2010) Kemampuan Bahasa Inggris mampu menunjang dan kesuksesan dalam bidang akademik sekaligus memberikan extra skill yang akan menunjang karir di dunia kerja (Sulistiana, Nadzifah and Arifin, 2019)

Penelitian Tindakan Kelas merupakan penelitian yang didasari atas permasalahan yang ditemukan dari kegiatan belajar mengajar didalam kelas (Kesuma, 2013). Dan dari pengalaman program praktik lapangan yang dilakukan penulis selama kurang lebih dua bulan di SMP Negeri 6 Singaraja didapatkan beberapa masalah yang mulcul pada saat pembelajaran di dalam kelas. Namun dari beberapa persamasalahan yang muncul selama kegiatan pembelajaran maka penulis memilih satu masalah yang mendasari semua permasalahan yang muncul didalam kelas tersebut yaitu masalah terbatasnya pembendaharaan kosakata (vocabulary) yang dikuasai oleh sebagian besar siswa didalam kelas VIII A1.

Penulis menyadari permasalahan ini dari berbagai bukti yang telah dikumpulkan selama dua bulan mengajar di kelas VIII A1. Diantaranya dari banyaknya siswa yang menanyakan kosakata dalam Bahasa Inggris yang relatif mudah dan sering digunakan pada saat proses pengerjaan penugasan. Selain itu juga dari hasil kerja siswa yang masih menggunakan kosakata yang monoton dan terbatas. Siswa pun kesulitan pada saat memahami teks meski mereka telah menggunakan teknik penerjemahan per kata dikarenakan banyaknya kosakata yang mereka tidak mengerti artinya sehingga menimbulkan ketidaksesuaian makna dari kalimat yang dibaca dan diterjemahkan. Bukti autentik juga dapat dilihat dari hasil pre-test yng dilakukan guru pada siswa kelas VIII A1 yang penunjukkan rendahnya hasil rata-rata pengetahuan siswa tentang kosakata Bahasa Inggris.

Keterbatasan kosakata yang dimiliki siswa kelas VIII A1 ini menimbulkan ketidaksempurnaan kemampuan berbahasa Inggris mereka dalam mengemangkan keempat keterampilan berbahasa Inggris. Maka dengan demikian penulis memutuskan membuat Penelitian Tindakan Kelas berjudul "Meningkatkan Pembendaharaan Kata Bahasa Inggris Melalui Strategi Crossword Puzzle Kelas VIII A1 SMP Negeri 6 Singaraja". Dengan melakukan penelitian terkait strategi peningkatan pembendaharaan kosakata siswa diharapkan menunjukan peningkatan pembendaharaan kosakata yang diharapkan akan membantu siswa meningkatkan kemampuan keempat keterampilan berbahasa Inggris mereka.

Dan setelah mempertimbangkan berbagai strategi pembelajaran penulis memutuskan untuk menggunakan strategi pembangunan pembendaharaan kosakata menggunakan permainan crossword 
puzzles. Penulis memilih strategi crossword puzzles dengan pertimbangan bukti keberhasilan dari berbagai 3 penelitian yang dilakukan diberbagai negara. Diantaranya Aziza.

\section{Metode}

\section{Setting Penelitian dan Subyek Penelitian}

Penelitian Tindakan Kelas ini dilaksanakan di SMP Negeri 6 Singaraja. Pelaksanaan penelitian berlangsung kurang lebih satu bulan dimulai dari tahap perencanaan pada minggu kedua bulan Maret sampai tahap analisis data pada minggu pertama bulan Mei. Subyek penelitian dalam penelitian ini adalah seluruh siswa dan siswi kelas VIII A1 SMP Negeri 6 Singaraja sebanyak 32 orang ynag terdiri dari 16 orang siswa dan 16 orang siswi.

\section{Prosedur Penelitian \\ Fase Perencanaan}

Selama satu bulan pertama mengajar peneliti melakukan observasi di dalam kelas VIII A1 yang menjadi subyek penelitian untuk menemukan permasalahan yang dihadapi kelas VIII A1 dalam memahami materi pelajaran Bahasa Inggris. Setelah menemukan masalah maka selanjutnya peneliti beralih kepada tahap perencanaan pelitian.

Rancangan penelitian dimulai dari menentukan kompetensi dasar dan focus materi yang akan digunakan sebagai bahan penelitian. Kemudian peneliti menentukan jenjang yang tepat untuk diaplikasikan kepada subyek penelitian. Kesemuanya tersebut akan dilampirkan dalam bentuk Rencana Pelaksanaan Pembelajaran (RPP) dengan kurikulum K-13 sesuai dengan kurikulum yang diterapkan di SMP Negeri 6 Singaraja. Dalam RPP tersebut juga dilampirkan langkah-langkah pembelajaran dimana instrument crossword puzzle diberikan sebagai strategi peningkatan pembendaharaan kosakata Bahasa Inggris siswa. Selanjutnya peneliti melaksanakan pre-test untu mengetahui secara pasti batas level kemampuan seluruh siswa di kelas VIII A1.

\section{Fase Tindakan dan Observasi}

Setelah dipastikan batas level kemampuan seluruh siswa di kelas VIII A1 adaalah dibawah rata-rata melalui pre-test maka peneliti melanjutkan penelitian dengan melaksanakan rencana pembelajaran yang telah disusun dengan strategi yang telah ditentukan. Kemudian peneliti melaksanakan penelitian siklus pertama didalam kelas VIII A1 dalam jangka waktu 2 jam pelajaran atau diakumulasikan menjadi 2 x 40 menit. Dalam fase tindakan peneliti mengaplikasikan strategi crossword puzzle yang telah dipilih sebagai strategi peningkatan kemampuan kosakata siswa.

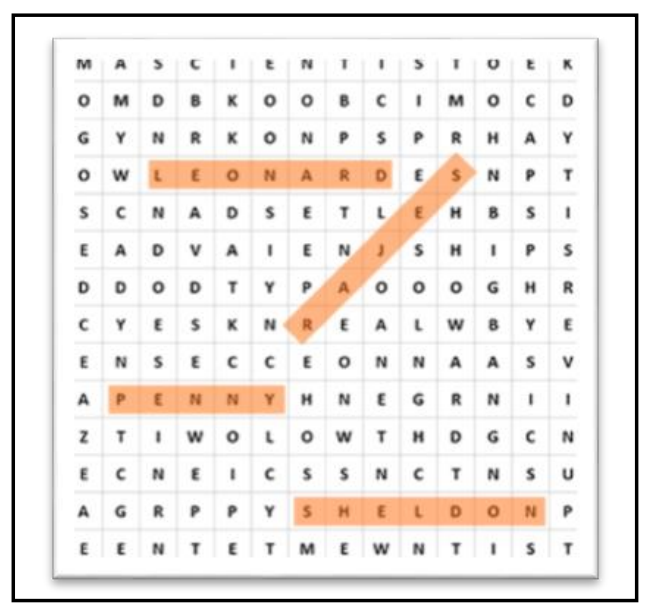

Gambar 1. Word Box

Selama proses aplikasi strategi guru juga melakukan observasi terkait respon siswa terhadap strategi yang diaplikasikan. Selanjutnya peneliti melakukan post-test terkait kemampuan pembendaharaan kosakata Bahasa Inggris siswa setelah dilakukannya pengaplikasian strategi crossword puzzle.

\section{Fase Refleksi}

Setelah penelitian dilaksanakan peneliti melakukan analisis hasil penelitian dengan membandingkan nilai pre-test dan post-test dari pelaksanaan penelitian. Selanjutnya hasil analisis didukung dengan data respon siswa terkait strategi yang telah diberikan. Hasil dari perbandingan yang didukung dengan respon siswa akan menunjukkan apakah pengaplikasian strategi crossword puzzle 
berperan baik dalam meningkatkan pembendaharaan kosakata Bahasa Inggris siswa kelas VIII A1 SMP Negeri 6 Singaraja.

\section{Data dan Cara Pengambilan Data}

Data yang dibutuhkan dalam penelitian ini adalah nilai pre-test sebelum strategi diaplikasikan untuk mengetahui secara pasti level kekurangan kemampuan kosakata siswa. Data pre-test diambil dengan cara memberikan siswa 30 pertanyaan terkait kosakata Bahasa Inggris dalam bentuk multiple choice. Setelah dipastikan level kemampuan siswa maka data selanjutnya yang harus dikumpulkan adalah data nilai post-test setelah diaplikasikannya strategi yang menjadi focus penelitian. Data ini juga dikumpulkan dengan cara memberikan tugas kepada peserta didik untuk mengembangkan kosakata yang baru dipelajari menjadi kalimat lengkap. Dari kalimat yang dibuat dapat disimpulkan keberhasilan pemahaman peserta didik dari konteks kalimat yang digunakan. Selanjutnya data pendukung berupa respon siswa terkait dengan strategi crossword puzzle dikumpulkan dengan memberikan siswa questionnaire berisi empat pertanyaan terkait crossword puzzle.

\section{Indikator Kinerja} berikut :

Indikator yang menjadi tolak ukur keberhasilan Penelitian Tindakan Kelas ini adalah sebagai

1. PTK dapat dikatakan berhasil jika nilai rata-rata post-test siswa setelah diaplikasikannya strategi crossword puzzle mencapai atau sama dengan nilai KKM (Kriteria Ketuntasan Minimal) yang ditetapkan sekolah yaitu sebesar 75 poin.

2. PTK dapat dikatakan berhasil jika $75 \%$ nilai post-test siswa dapat mecapai atau sama dengan nilai KKM (Kriteria Ketuntasan Minimal) yang ditetapkan sekolah yaitu sebesar 75 poin.

\section{Analisis Data}

Data yang telah diperoleh akan dianalisis dengan teknik penilaian perbandingan dimana hasil dari pre-test akan dibandingkan dengan hasil post-test. Selanjutnya hasil Dari hasil perbandingan tersebut akan diketahui tingkat peningkatan yang terjadi setelah diaplikasikannya strategi crossword puzzle pada siswa kelas VIII A1.

\section{Hasil Dan Pembahasan}

\section{Pre-Test}

Sebelum penulis melaksanakan penelitian tindakan kelas ini dibutuhkan data autentik terkait pengetahuan siswa mengenai pembendaharaan kosakata yang dari pengamatan sebelumnya dirasa kurang. Maka dari itu peneliti mengambil data pre-test terkait kemampuan pembendaharaan kosakata siswa kelas VIII A1. Pre-test ini dilaksanakan pada tanggal 19 Maret 2019. Hasil pre-test dapat dijabarkan sebagai berikut :

Tabel 1. Hasil Pre-Test

\begin{tabular}{|c|c|c|}
\hline No. & Nama & Pre-Test \\
\hline 1. & Putu Agni Jegeg Ravindra & 96 \\
\hline 2. & Anak Agung Made A. M. P. & 78 \\
\hline 3. & Putu Agus Arya Utama & 81 \\
\hline 4. & I Putu Abimanyu Budi P. & 96 \\
\hline 5. & I Gusti Made Agus M. & 66 \\
\hline 6. & Made Adi Dwija Putra & 83 \\
\hline 7. & Gede Ari Subyakta & 86 \\
\hline 8. & Ketut Bayu Wicaksana & 93 \\
\hline 9. & Kadeh Dhea Ningtyas & 91 \\
\hline 10. & Ni Putu Dina Pradnyani & 65 \\
\hline 11. & I Kadek Dwi Andika P. P. & 61 \\
\hline 12. & Putu Indrawan Adi Nata & 60 \\
\hline 13. & Made Ayu Kirana Candrasari & 81 \\
\hline 14. & Maharani Purwaningtyas & 66 \\
\hline 15. & Natika Firda Kerista Anugrah & 86 \\
\hline 16. & I Nyoman Putra Satya Natha & 80 \\
\hline
\end{tabular}




\begin{tabular}{|c|c|c|}
\hline 17. & Ni Luh Putu Radha Laksmi & 96 \\
\hline 18. & Kadek Ratih Purwaningsih & 90 \\
\hline 19. & Komang Riyandi A. S. & 96 \\
\hline 20. & Ni Kadek Rosita Dewi & 86 \\
\hline 21. & Sang Ayu Dian Savita Dewi & 88 \\
\hline 22. & Ni Komang Sri N. M. & 66 \\
\hline 23. & Ni Luh Putu Sulastri & 66 \\
\hline 24. & Komang Tri Rahayu & 90 \\
\hline 25. & Ni Made Widhi Utami & 75 \\
\hline 26. & Ida Bagus Kade B. & 73 \\
\hline 27. & Kadeh Wirattami P. P. A. A. & 46 \\
\hline 28. & Kadek Mas Mawar Diana & 23 \\
\hline 29. & Made Widi Widiana & 61 \\
\hline 30. & Kadek Suwardana & 73 \\
\hline 31. & Putu Bayu Putra Pradnya & 10 \\
\hline 32. & Kadek Evi Puspita Dewi & 65 \\
\hline & Total & 2373 \\
\hline
\end{tabular}

Dari tabel hasil diatas pre-test kelas VIII A1 diatas dapat diketahui rata-rata nilai pre-test siswa terkait kemampuan pembendaharaan kosakata dengan perhitungan berikut:

$\frac{\text { Jumlah Nilai Siswa }}{\text { Jumlah Siswa }}=$ Rata - Rata Nilai Siswa $\quad \rightarrow \quad \frac{2373}{32}=74,156$

Dari hasil perhitungan diatasa dapat diketahui bahwa nilai rata-rata pre-test siswa terait kemampuan pembendaharaan kosakata adalah dibawah KKM yaitu sebesar 74,156. Dan persentasi siswa yang mendapat nilai diatas atau sama dengan KKM dapat diketahui dengan perhitungan sebagai berikut :

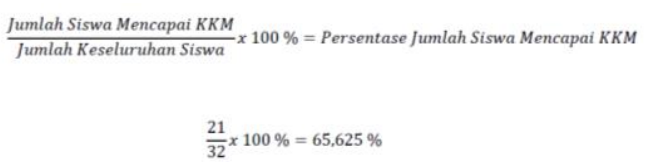

(2)

Dari hasil perhitungan diatas diketahui bahwa persentase jumlah siswa yang mencapai nilai KKM masih berada dibawah indikator keberhasilan PTK yaitu sebesar 65,625 \%. Dan kedua hasil analisis pretest tersebut membawa penulis pada kesimpulkan untuk melaksanakan PTK pada kelas VIII A1 untuk meningkatkan kemampuan pembendaharaan kosakata Bahasa Inggris.

\section{Siklus 1}

Setelah mendapatan hasil pre-test penulis melanjutkan penerapan strategi crossword puzzle. Siklus satu PTK dilaksanakan pada tanggal 20 Maret 2019. Penulis mengaplikasikan strategi crossword puzzle pada penugasan pertama, yang kemudian diikuti oleh tiga penugasan lanjutan dengan tingkat kesulitan yang semakin meningkat. Penulis menerapkan strategi ini dengan prinsip kompetisi, dimana masingmasing siswa secara individu harus menyelesaikan satu tugas untuk dapat melanjutkan tugas selanjutnya.

Dan untuk menambah tantangan dalam kompetisi penulis memberikan perhargaan kepada sepuluh siswa yang dapat menyelesaikan seluruh rangkaian tugas. Prinsip kompetisi dengan penghargaan kepada yang tercepat menyelesaikan tugas dapat memacu siswa untuk segera mengumpulkan hasil kerja secepat mungkin setelah ia menyelesaikan tugas, hal ini akan menghalangi siswa tersebut untuk memiliki kesempatan membagikan jawaban yang telah ia buat. Dan hasil post-test siklus satu dapat dilihat pada table berikut :

Tabel 2. Hasil Post-Test 1

\begin{tabular}{|c|c|c|}
\hline No. & Nama & Post-Test 1 \\
\hline 1. & Putu Agni Jegeg Ravindra & 100 \\
\hline 2. & Anak Agung M. A. M. P. & 97 \\
\hline
\end{tabular}




\begin{tabular}{clc}
\hline 3. & Putu Agus Arya Utama & 77 \\
4. & I Putu Abimanyu Budi P. & 100 \\
5. & I Gusti Made Agus M. & 68 \\
6. & Made Adi Dwija Putra & 94 \\
7. & Gede Ari Subyakta & 94 \\
8. & Ketut Bayu Wicaksana & 91 \\
9. & Kadeh Dhea Ningtyas & 100 \\
10. & Ni Putu Dina Pradnyani & 97 \\
11. & I Kadek Dwi Andika P. P. & 68 \\
12. & Putu Indrawan Adi Nata & 77 \\
13. & Made Ayu Kirana C. & 77 \\
14. & Maharani Purwaningtyas & 65 \\
15. & Natika Firda Kerista A. & 77 \\
16. & I Nyoman Putra Satya N. & 100 \\
17. & Ni Luh Putu Radha Laksmi & 94 \\
18. & Kadek Ratih Purwaningsih & 82 \\
19. & Komang Riyandi A. S. & 100 \\
20. & Ni Kadek Rosita Dewi & 71 \\
21. & Sang Ayu Dian Savita D. & 100 \\
22. & Ni Komang Sri N. M. & 100 \\
23. & Ni Luh Putu Sulastri & 65 \\
24. & Komang Tri Rahayu & 95 \\
25. & Ni Made Widhi Utami & 80 \\
26. & Ida Bagus Kade B. & 85 \\
27. & Kadeh W. P. P. A. A. & 60 \\
28. & Kadek Mas Mawar Diana & 62 \\
29. & Made Widi Widiana & 80 \\
30. & Kadek Suwardana & 88 \\
31. & Putu Bayu Putra Pradnya & 37 \\
32. & Kadek Evi Puspita Dewi & 94 \\
& & 2675 \\
\hline & & \\
\hline
\end{tabular}

Dari hasil post-test siklus satu kelas VIII A1 diatas dapat diketahui rata-rata nilai post-test siklus satu siswa terkait kemampuan pembendaharaan kosakata setelah diaplikasikan strategi crossword puzzle dengan perhitungan berikut:

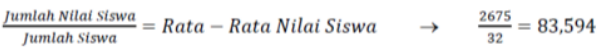

Dari hasil perhitungan diatasa dapat diketahui bahwa nilai rata-rata post-test siklus satu siswa terait kemampuan pembendaharaan kosakata adalah mencapai KKM yaitu sebesar 83,594. Dan persentasi siswa yang mendapat nilai diatas atau sama dengan KKM dapat diketahui dengan perhitungan sebagai berikut :

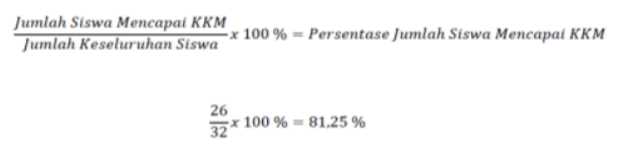

Dari hasil perhitungan diatas diketahui bahwa persentase jumlah siswa yang mencapai nilai KKM sudah mencapai indikator keberhasilan PTK yaitu sebesar 81,25 \%. Dan kedua hasil analisis post-test siklus satu tersebut dapat disimpulkan bahwa pengaplikasian strategi crossword puzzle untuk meningkatkan pembenddaharaan kosakata siswa telah memenuhi kedua indikator kinerja PTK dan dapat 
dikatakan berhasil. Keberhasilan pembendaharaan kata mengalami kenaikan sebanyak 9,438 \%. Dan jumlah siswa yang mencapai nilai KKM meningkat sebesar 15,625 \%.

\section{Siklus 2}

Siklus dua dilaksanakan seminggu setelah dilaksanakannya siklus satu yang tepatnya pada tanggal 10 April 2019. Pelaksanaan siklus dua tidak jauh berbeda dari silkus satu, perbedaan hanya terdapat pada pemberian penghaargaan diberikan kepada sepuluh siswa yang pertama mengumpulkan tugas akhir. Ini sedikit berbeda dari siklus satu dimana pemberian penghargaan diberikan pada sepuluh siswa yang menyelesaian tugas pada setiap penugasan. Dan nilai post-test siklus dua dapat dilihat pada tabel berikut :

Tabel 3. Hasil Post-Test 2

\begin{tabular}{|c|c|c|}
\hline No. & Nama & Post-Test 2 \\
\hline 1. & Putu Agni Jegeg Ravindra & 88 \\
\hline 2. & Anak Agung M. A. M. P. & 89 \\
\hline 3. & Putu Agus Arya Utama & 80 \\
\hline 4. & I Putu Abimanyu Budi P. & 95 \\
\hline 5. & I Gusti Made Agus M. & 80 \\
\hline 6. & Made Adi Dwija Putra & 85 \\
\hline 7. & Gede Ari Subyakta & 93 \\
\hline 8. & Ketut Bayu Wicaksana & 90 \\
\hline 9. & Kadeh Dhea Ningtyas & 99 \\
\hline 10. & Ni Putu Dina Pradnyani & 98 \\
\hline 11. & I Kadek Dwi Andika P. P. & 85 \\
\hline 12. & Putu Indrawan Adi Nata & 85 \\
\hline 13. & Made Ayu Kirana C. & 80 \\
\hline 14. & Maharani Purwaningtyas & 88 \\
\hline 15. & Natika Firda Kerista A. & 83 \\
\hline 16. & I Nyoman Putra Satya N. & 80 \\
\hline 17. & Ni Luh Putu Radha Laksmi & 100 \\
\hline 18. & Kadek Ratih Purwaningsih & 96 \\
\hline 19. & Komang Riyandi A.S. & 95 \\
\hline 20. & Ni Kadek Rosita Dewi & 95 \\
\hline 21. & Sang Ayu Dian Savita D. & 99 \\
\hline 22. & Ni Komang Sri N. M. & 100 \\
\hline 23. & Ni Luh Putu Sulastri & 63 \\
\hline 24. & Komang Tri Rahayu & 100 \\
\hline 25. & Ni Made Widhi Utami & 83 \\
\hline 26. & Ida Bagus Kade B. & 80 \\
\hline 27. & Kadeh W. P. P. A. A. & 60 \\
\hline 28. & Kadek Mas Mawar Diana & 63 \\
\hline 29. & Made Widi Widiana & 75 \\
\hline 30. & Kadek Suwardana & 80 \\
\hline 31. & Putu Bayu Putra Pradnya & 28 \\
\hline 32. & Kadek Evi Puspita Dewi & 90 \\
\hline \multicolumn{2}{|r|}{ Total } & 2705 \\
\hline
\end{tabular}

Dari hasil post-test siklus dua kelas VIII A1 diatas dapat diketahui rata-rata nilai post-test siklus dua siswa terkait kemampuan pembendaharaan kosakata setelah diaplikasikan strategi crossword puzzle dengan perhitungan berikut: 
$\frac{\text { Jumlah Nilai Siswa }}{\text { Jumlah Siswa }}=$ Rata - Rata Nilai Siswa $\rightarrow \quad \frac{2705}{32}=84,531$

Dari hasil perhitungan diatas dapat diketahui bahwa nilai rata-rata post-test siklus dua siswa terkait kemampuan pembendaharaan kosakata adalah mencapai KKM yaitu sebesar 84,531. Dan persentasi siswa yang mendapat nilai diatas atau sama dengan KKM dapat diketahui dengan perhitungan sebagai berikut :

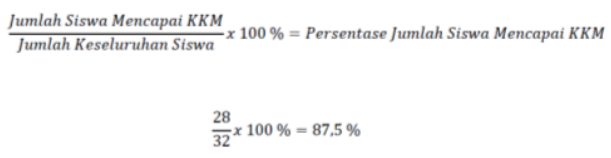

Dari hasil perhitungan diatas diketahui bahwa persentase jumlah siswa yang mencapai nilai KKM sudah mencapai indikator keberhasilan PTK yaitu sebesar 87,5 \%. Dan kedua hasil analisis post-test siklus dua tersebut dapat disimpulkan bahwa pengaplikasian strategi crossword puzzle untuk meningkatkan pembendaharaan kosakata siswa telah memenuhi kedua indikator kinerja PTK dan dapat dikatakan berhasil. Keberhasilan pembendaharaan kata mengalami kenaikan sebanyak 10,375 \%. Persentase tersebut juga meningkat dibandingkan dengan post-test siklus satu yang awalnya sebesar 9,438\%. Dan jumlah siswa yang mencapai nilai KKM meningkat sebesar 21,875 \% yang juga meningkat dari siklus satu yang awalnya sebesar $15,625 \%$.

\section{Angket}

Setelah seluruh rangkaian PTK dilaksanakan siswa diminta untuk mengisi angket terkait perasaan siswa tentang strategi crossword puzzle yang telah mereka kerjakan sebelumnya. Hasil angket dapat dijabarkan dalam diagram berikut:

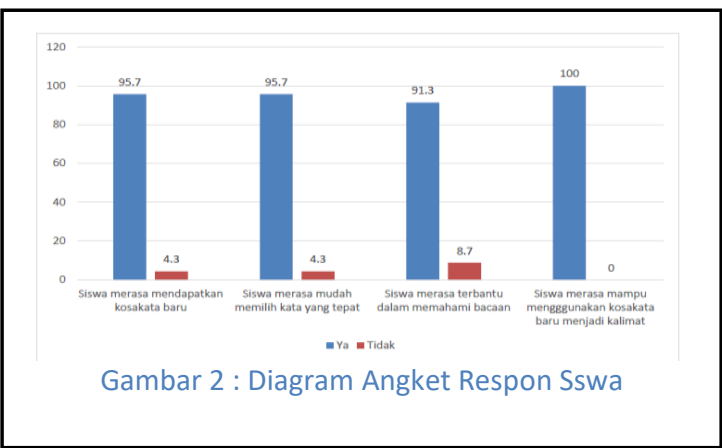

Gambar 2. strategi crossword puzzle

Dari gambar 2 pertama diperoleh sejumlah 95,7 \% siswa merasa strategi crossword puzzle dapat membantu mereka mendapatkan kosakata baru. Kedua sejumlah 95,7 siswa merasa dapat memilih kosakata yang tepat untuk suatu konteks bacaan dengan tepat. Ketiga sejumlah 91,3 \% siswa merasa terbantu dalam memahami keseluruhan isi bacaan. Dan keempat sejumlah $100 \%$ siswa merasa mampu menggunakan kosakata baru kedalam kalimat.

\section{Simpulan}

Dari hasil analisis nilai akhir pengaplikasian strategi crossword puzzle untuk meningkatkan penguasaan pembedaharaan kosakata Bahasa Inggris yang telah dijabarkan pada bab sebelumnya dapat diambil kesimpulan bahwa strategi crossword puzzle berhasil meningkatkan penguasaan pembendaharaan kosakata Bahasa Inggris siswa kelas VIII A1 SMP Negeri 6 Singaraja. Hal ini disimpulkan dari nilai hasil post-test siklus satu yang meningkat dibandingkan dengan nilai hasil pre-test. Dan hasil pada siklus satu telah mendapatkan konfimasi pada hasil siklus dua yang jug mengalami peningkatan dibandingkan dengan nilai hasil pre-test. Bahkan nilai hasil post-test dua ini pun meningkat dibandingkan dengan siklus satu. Hasil tersebut juga didukung dengan data angket respon siswa terhadap penggunaan strategi crossword puzzle dalam meningkatkan pembendaharaan kosakata Bahasa Inggris. Dan kesimpulan dari angket respon siswa tersebut dapat disimpulkan bahwa siswa merasa strategi crossword puzzle dapat meningkatkan kemampuan pembendaharaan kosakata mereka secara signifikan. 


\section{Daftar Pustaka}

Astuti, W. and Habibah, U. (2015) 'Peningkatan Kemampuan Kosakata Bahasa Inggris Anak Melalui Metode Pembelajaran Interaktif Di Kelompok a Tk Pertiwi I Jirapan 2014/2015', Prosiding Seminar Nasional dan Call For Papers, ISBN: 978-(2), pp. 323-332.

Kesuma, A. (2013) Menyusun PTK Itu Gampang. Jakarta: Esensi.

Njoroge, M.C., Ndung'u, R.W., Gathigia, M. . (2013) 'The Use of Crossword puzzles as a Vocabulary Learning Strategy: A Case of English as Second Language in Kenyan Secondary Schools', Karatina University College.

Ramdhan, V. (2017) 'Pengaruh Penguasaan Kosakata dan Tata Babasa Terhadap Pemahaman Membaca Teks Narasi bahasa Inggris (The influence of the mastery of vocabulary and Grammar Babasa Against reading comprehension Text English Narration)', Deiksis, 09(02), pp. 240-246.

Sholichah, A. S. (2018) 'Teori-Teori Pendidikan Dalam Al-Qur'an', Edukasi Islami : Jurnal Pendidikan Islam, 7(01), p. 23. doi: 10.30868/ei.v7i01.209.

Sudrajat, H. N. and Herlina, H. (2015) 'Meningkatkan Pemahaman Kosakata Bahasa Inggris Melalui Metode Permainan Bingo', JIV-Jurnal Ilmiah Visi, 10(2), pp. 114-121. doi: 10.21009/jiv.1002.6.

Sulistiana, E., Nadzifah, W. and Arifin, M. S. (2019) 'Intensive English Program (IEP) Meningkatkan Penguasaan Vocabulary', Jurnal Studi Guru dan Pembelajaran, 2(3), pp. 236-240. doi: 10.30605/jsgp.2.3.2019.46.

Zalmansyah, A. (2013) 'Meningkatkan perbendaharaan kata (vocabulary) siswa dengan menggunakan komik strip sebagai media pembelajaran bahasa Inggris', Kandai, 9(2), pp. 262-275. 